\title{
Application of the Principles of Coordination between Polri Investigators and Prosecutors in Processing Criminal Cases in the Legal Territory of the Pontianak Police, West Kalimantan City
}

\author{
Fery Suryono ${ }^{1)}$, Kawakib ${ }^{2)}$ \\ ${ }^{1,2)}$ Syarif Abdurrahman College of Sharia Sciences (STIS) Pontianak, West Kalimantan, Indonesia \\ Corresponding Author: Fery Suryono, Email: feryfelis@gmail.com
}

\begin{abstract}
History: Received 05/12/2021 | Revised 08/12/2021 $\mid$ Accepted 28/12/2021 $\mid$ Published 31/01/2022
Abstract. The purpose of this article is to find out the actual duties and authorities of the implementation of the principle of coordination between the police investigators and prosecutors in the process of handling criminal cases in law enforcement agencies as regulated in the Criminal Procedure Code because in practice in the field it is often found that in handling crime problems there are no following reality and in the end investigators and public prosecutors gave rise to a negative stigma in the judge's decision. The type of research methodology in this article is normative juridical. Normative legal research focuses on doctrine by analyzing legal rules found in statutory regulations or various judges' decisions. The data presented are descriptive and analytical symptoms that occur in the field, namely between investigators, public prosecutors, and judges with the rule of law or actions with norms according to legal principles. Therefore, the obstacles that limit the implementation of the principle of coordination between Polri investigators and the public prosecutor include The lack of communication and coordination between the Polri and the public prosecutor because those who prioritize the interests of their institutions without paying attention to the interests of other parties, and lack of trust in Polri and other law enforcers, as is the stigma that grows in the community today, makes it difficult for the Police to carry out their duties in the field; neglect of resource aspects in law enforcement; not yet the same vision and opinion of law enforcers; and have not understood the doctrine, professional ethics of the Police by investigators causing the morale of the investigators to below, in addition to problems with welfare, equipment, and limited investigative funds
\end{abstract}

Keywords: National Police Investigator, Public Prosecutor, Asas coordination

Abstrak. Tujuan artikel ini penulis ingin mengetahui tugas dan wewenang yang sebenarnya terhadap penerapan asas koordinasi penyidik polri dengan jaksa dalam proses menangani kriminalisasi perkara pidana diwilayah penegak hukum sebagaimana yang telah diatur dalam Undang-Undang KUHAP, karena prakteknya di lapangan seringkali ditemukan bahwa dalam penanganan permasalahan tindak pidana tidak sesuai dengan kenyataan dan pada akhirnya penyidik dan jaksa penuntut umum memunculkan stigma negatif dalam putusan hakim. Jenis metodologi penelitian artikel ini bersifat yuridis normatif yaitu; penelitian hukum normatif berfokus pada doktrin melalui analisis kaidah hukum yang ditemukan dalam peraturan perundang-undangan atau dalam berbagai putusan hakim. Data yang disajikan bersifat deskriptif dan analitis yaitu gejala yang terjadi di lapangan yaitu antara penyidik, jaksa penuntut umum dan hakim dengan aturan hukum atau tindakan dengan norma-norma sesuai prinsip hukum. Oleh karena itu, kendala-kendala yang membatasi pelaksanaan asas koordinasi antara penyidik Polri dengan Jaksa Penuntut umum antara lain: Minimnya komunikasi dan koordinasi antara Polri serta jaksa penuntut umum, karena yang lebih mengedepankan kepentingan lembaganya sendiri tanpa mencermati kepentingan pihak lain, serta kekurang percayaan kepada Polri serta penegak hukum yang lain, sebagaimana stigma yang tumbuh di warga dikala ini menyebabkan Polri kesulitan dalam melaksanakan tugas di lapangan; pengabaian aspek sumberdaya dalam penegakan hukum; belum samanya visi serta anggapan para penegak hukum, etika profesi Kepolisian oleh penyidik menyebabkan moral aparat penyidik rendah, disamping itu permasalahan kesejahteraan, perlengkapan, dana penyidikan yang terbatas.

Kata Kunci: Penyidik Polri, Jaksa Penuntut Umum, Asas koordinasi. 


\section{INTRODUCTION}

The concept of the Criminal Justice System in Indonesia as regulated in the Law of the Republic of Indonesia Number 8 of 1981 concerning the Criminal Procedure Code, when viewed from the power or authority, is built by 4 (four) Subsystems, namely consisting of investigations under the authority of the Police and PPNS, prosecution under the authority of the Prosecutor Public Prosecutor, and examination before a court session which is the authority of the Judge, and guidance which is the authority of the Correctional Institution. These subsystems in the criminal justice system are expected to work together in synergy to form an integrated criminal justice system, namely the existence of a common opinion or perception of the objectives of the criminal justice system so that every institution involved in the criminal justice process does not only see the interests of each. -each institution, but in the interest of the entire Criminal Justice System (Murtiono \& Ik, t.t.).

The birth of KUHAP was very well received by the legal world and recognized as a milestone of legal change, especially in the Indonesian KUHAP. KUHAP serves as a guideline for Police, prosecutors, and judges (including legal counsel) to conduct investigations and arrests. Detention and investigation of the legal process. The Criminal Code has been strictly regulated, the duties and authorities of the Police as investigators and investigators and prosecutors as public prosecutors. Override the duties and authority of the Police as investigators and investigators are regulated in Article 4 to Article 12 of the Criminal Code. The duties and authority of the prosecutor as a public prosecutor are regulated in Article 13 to Article 15 of the Criminal Code. The duties and authorities of the Police for Law No. 2 of 2002 on the State Police of the Republic of Indonesia are listed in Article 13 to Article 19. Conversely, the duties and authorities of the prosecutor as a public prosecutor are contained in Law Number. 16 of 2004 on the Prosecutor's Office of the Republic of Indonesia as in Articles 8, 9, and 30 (Kusuma Winahayu, t.t.).

The principle of coordination between the Police and the Prosecutor's Office is regulated in the Criminal Procedure Code. The need for coordination between investigators and prosecutors begins with the notification of the start of an investigation (SPDP) being sent by the investigator to the public prosecutor as regulated in Article 109 paragraph (1) of Law No. 8 of 1981) (Justicia et al., 2016). The investigators and public prosecutors are not meant to clarify authority and work efficiency duties. Still, they are directed at fostering law enforcement officers burdened with responsibilities to cooperate (Yustisia, Pratiwi, et al., 2015). Positive coordination between police investigators and prosecutors must be well established to smooth the judicial process of each criminal case. Suppose positive coordination and cooperation are not well 
established. In that case, it will have a negative impact on the judicial process, especially the occurrence of arrears in cases at the High Prosecutor's Office and the District Attorney's Office. This can have a negative impact on law enforcement and justice because many cases cannot be processed in accordance with applicable legal provisions. This is where the law is expected to play a role in overcoming these problems

Although juridically-normatively, both in the Herzeine Inlands Reglement (HIR) and in the Criminal Procedure Code, the duties and authorities have been regulated as well as the respective institutions that must carry them out, disputes and disharmony of responsibilities and authorities between institutions in our criminal justice system still often arise. The dispute is sometimes even so sharp that it creates cynicism in society. The struggle for authority to investigate specific crimes (such as corruption) between the Police and the Prosecutors often makes negative opinions in the community. Coordination and cooperation between Police Investigators and Public Prosecutors must be well established to smooth the judicial process of each criminal case. On the other hand, if the coordination and cooperation are good, it will impact the judicial process, especially the occurrence of arrears in payment of cases in services, because many cases cannot be processed according to the applicable legal provisions.
In applying the principle of coordination between Polri Investigators and Prosecutors in Processing Criminal Cases, law enforcement in crime investigation activities is not integrated so that security and law enforcement will not be optimal. There are three forms of working procedures, technical guidance and operational assistance in investigations. Certain civil servant investigators in carrying out their duties are under the coordination and supervision of investigators (Manik, 2018). Arwinsyah believes that the relationship between investigators and the Prosecutor's Office has been regulated in Law Number 8 of 1981 when conducting criminal investigations and notified to the Prosecutor's Office, starting with the Police (POLRI Investigators) who are authorized to carry out investigations. The Prosecutor's Office conducts the prosecution stage, in which the Kasi Pidum/Pidsus manage the SPDP to appoint prosecutors who research case files from investigators and determine whether the case files can be transferred to the Court and returned to the Investigators or vice versa in settlement of Criminal Cases If the Prosecutor's Office does Not accept the Results of the POLRI Investigations. carried out by Pre-prosecution and Additional Examination by completing the case file is carried out by taking into account the completeness of the material and formal requirements of the case file, sufficient initial evidence with the principle of mutual 
coordination, the principle of fast justice, low and simple costs and functional differentiation (Napitu, 2016). Agus Syahputra thinks that showing functional coordination between Polri investigators and the Prosecutor's Office at the pre-crisis stage is continuous. Delays in completing case files by investigators often occur because of the difficulty of collecting evidence. The ideal form of functional coordination between Polri investigators and the Prosecutor's Office at the pre-crisis stage is functional coordination and consolidation (Saputra, 2019).

To overcome the problems in law enforcement agencies between police investigators and public prosecutors regarding the lack of coordination, especially law enforcers at the Pontiak Police Station, West Kalimantan. Based on data collected from the Pontianak City Police, that the Notification of the Commencement of Investigations sent from the Pontianak City Police every year increases in criminal cases so that the case process has not been carried out properly because between the investigators and the public prosecutor and the prosecutor lack of coordination and good communication in handle criminal cases. These problems must be avoided because as law enforcers, especially investigators, public prosecutors, prosecutors, provide examples with and procession in handling criminal cases and provide examples and influence in people's lives, because their function is to guide, provide guidelines, sanctions and tools to engineer the establishment of coordination and positive cooperation between Police Investigators and Prosecutors.

\section{RESEARCH METHODS}

The approach used in this research was normative legal research or normative juridsch onderzoek in German called normative juristische recherché. Normative legal research is one of law scholars' most widely conducted studies. From the community (Ali, 2021). Soetandyo Wignjosoebroto stataes that normative legal research is termed doctrinal bridge research, namely research on the law that is conceptualized on the basis of the doctrine adopted; "There are various doctrines that have been adopted and developed in legal studies, ranging from the classical doctrine known as the natural law doctrine (school) of the philosophers and the jurist-legal positivism (school) doctrine to the historical doctrine and the realism-functionalism doctrine of the philosophers. Legal experts who are considered realists. In Indonesia, this doctrinal method is commonly referred to as a normative legal research method (Jonaedi Efendi \& Johnny Ibrahim, 2018).

Referring to the description above, it was seen that normative legal research basically has its own characteristics. First, normative legal research focused on doctrine through analysis of legal rules found in laws and regulations or in various judges' decisions. 
Second, because it relied on formal law, the source of the data was secondary data consisting of primary, secondary and tertiary legal materials obtained through library research and not familiar with field research. Third, as a consequence, in normative legal research there was no need for sampling because secondary data had its own weight and quality that could no replaced with other data. fourth, normative research used a priori studies, deductive syllogistic reasoning and interpretation methods to explain a legal phenomenon. Five normative legal studies were descriptive and analytical on symptoms in the social field. The six normative juridical studies found and answered the truth of the problem by a coherent problem formulation that was under the rule of law or actions with norms according to legal principles (Made Pasek Diantha, 2016).

\section{DISCUSSION}

\section{Criminal Justice System}

In simple terms, the Criminal Justice System can be understood as an attempt to understand and answer the question of what the duties of criminal law are in society and not just how criminal law is contained in the law and how judges apply it. The enactment of Law No. 8 of 1981 concerning Criminal Procedure Law has 4 (four) subsystems, namely: the police subsystem, which is administratively under the President, the Attorney General's Office under the Attorney
General's Office, and correctional institutions under the Ministry of Justice. one of the objectives of the criminal justice system is; short-term, if what is to be achieved is the resocialization and rehabilitation of criminals, categorized as a medium-term goal, if what is being targeted is broader, namely control in crime prevention in the context of criminal politics (criminal policy) and long-term goal if what is to be achieved is the welfare of the community. (social welfare) in the context of social politics (social policy) (Muladi, 1995).

In the criminal justice system, there is input-process-output. As for what is meant by input is a report/complaint regarding the occurrence of a criminal act. In contrast, the process is taken by the police, prosecutors, courts, and correctional institutions. In contrast, the outputs are obtained results (Hantoro et al., 2018). Therefore, the four subsystems have an inseparable relationship because they have one goal but have different tasks.

\section{Indonesian National Police (Polri)}

Police of the Republic of Indonesia (Polri) as the first agency involved in the mechanism of the Criminal Justice System (Criminal Justice System), in carrying out their duties guided by Law Number 2 of 2002 concerning the Police, which has duties and authorities, among others: Receiving complaints, arresting people, detaining people (Article 14) The Police also participate 
physically in defense of the State (Article 13)

(Laws and regulations concerning the state police of the Republic of Indonesia, 2008).

Meanwhile, according to Law Number 8 of 1981 concerning the Criminal Procedure Code, the Police have the authority and are declared as investigators (Article 4 of the Criminal Procedure Code), investigators (Article 6), make Minutes of Examination (Article 75), have the discretion to stop investigations (Article 109 ), determining (citing) what criminal acts were committed by the suspect (Article 121). The Police also have discretion in implementing the given mandate. The Police are also given the main task, namely making decisions on the spot. The decision at that time resulted in something essential, namely how the law was applied (especially the recognition of the suspect's human rights). The Police's discretion which was ratified by Law Number 8 of 1981 by several academics and practitioners, was felt to influence the attitude of the Police themselves greatly. The existence of Discretion of Power does not rule out the possibility of abuse of power (A Buse of Power). This will disrupt the judicial process and the principles of justice (Laws and regulations concerning the Indonesian National Police 2008).

\section{The Public Prosecution Service of the Republic of Indonesia}

The Public Prosecution Service of the Republic of Indonesia is a government agency that exercises state power in prosecution and other authorities based on the provisions of the legislation. Human rights violations and others are based on the law (Effendy, 2005). Meanwhile, the main task of the public prosecutor's office is stated in Article 16-30-27 of the Law on the Prosecutor's Office of the Republic of Indonesia of 2004 that he is obliged to exercise state power in the field of law enforcement. Monitoring state functions and development performance in the legal field (Limbong, 2017). The Prosecutor's Office carries out the following functions in carrying out its duties:

1. Develop implementation and expert policies, provide instructions and guidance, and issue approvals.

2. Development of infrastructure and factories, development of management, management, organization and management, and implementation of the management of State property.

3. Certainty of preventive and oppressive law enforcement with justice in the field of crime, utilization of judicial messages in public order and morality, peace, support, consideration, service, and prosecution in civil and state administration. And other duties to secure, enforce government authority and protect national property.

4. Placing the suspect or defendant in the proper place based on a court decision

5. Legal considerations for institutions, central and regional government agencies, 
state-owned enterprises, and regional business entities in drafting laws and regulations and increasing public legal awareness.

6. Coordination, technical guidance and guidance within and with the responsible bodies, and proper supervision in implementing the mission, following the provisions of laws and regulations stipulated by the President.

The Attorney General's Office is supervised by the Attorney General's Office, which oversees six Attorney Generals and 31 Chief Prosecutor's Offices in each state in carrying out their duties and authorities. UU no. 200416 concerning the Prosecutor's Office of the Republic of Indonesia. The Prosecutor's Office is on the middle axis and acts as a filter between the preliminary examination and the examination process at trial, as well as court decisions and implementation of decisions (Effendy, 2005). Therefore, according to the Criminal Procedure Code, only the prosecutor can decide whether a case can be brought to court based on valid evidence. Then the prosecutor can determine the process of the case. According to Law Number 8 of 1981 concerning the Criminal Procedure Code, the prosecutor's office has the authority (Article 14) to include receipt and examination of files, prosecution, submission of cases to court, and licensing (Article 13). ) Too. Extension of detention, enforcement of detention. The most fundamental principle of criminal justice is the need for prosecution. If it is not clear, it will affect the judge's judgment and not be accepted (Effendy, 2005).

According to Law Number 8 of 1981 concerning the Criminal Procedure Code, prosecutors include, among others, public prosecutors who are authorized to receive and examine files, hear, and submit cases to court (Article 13) as well as permit extension of detention and carry out detentions. The most fundamental principle of the criminal justice process is preparing an indictment. If it is not clear, it affects the judge's judgment and makes it unacceptable (Watulingas \& Kumampung, t.t).

\section{Coordination between Police Investigators and Prosecutors}

In the criminal justice system, the police and the prosecutor's office are two law enforcement agencies that work very closely. These two institutions need to work together and coordinate well to achieve their goals. Characterized by a sincere spirit of synchrony, harmony, unity, and cooperation, the criminal justice system is a criminal justice system according to the Pancasila state lifestyle (Atmasasmita, 2010). Muladi said the criminal justice system is a court that uses substantive law, standard criminal law, and criminal law. But these institutions must be seen in a social context. The importance of an integrated criminal justice system is the principle of synchronization of similarities, one of which 
can be distinguished from structural synchronization, namely harmony in the context of relations between law enforcement agencies (Muladi, 1995).

Under criminal law, law enforcement authorities stop dealing with criminal proceedings. Legality, balance, the principle of presumption of innocence, limitation, compensation and reintegration, consolidation of criminal charges and losses, the principle of union, the principle of functional differentiation, the principle of mutual coordination, the principle of simple, fast and inexpensive procedures, the principle of publicly available procedures (Yustisia, Pratiwi, et al, 2015). These principles give rise to a pattern of investigator-prosecutor relations in the Criminal Procedure Code, where the police investigator is the main investigator and the public prosecutor is the public prosecutor. The Prosecutor's Office carries out an investigative service function that confirms the investigation results sent by the investigator, the BAP, and the Prosecutor's Office investigates the BAP and provides his opinion. For the Ikad system, it may not work due to inconsistencies. This gives rise to different perceptions of each other and can blame each other (Santoso, 2000).

The functional coordination relationship between the investigator and the public prosecutor, namely the investigator is obliged to notify the public prosecutor of the start of the investigation. (Article 109, Paragraph 1)
The public prosecutor must notify the public prosecutor of the termination of the investigation in order to submit the case to the court (Djamin, 2007). Meanwhile, suppose the results of the prosecutor's examination are considered incomplete. In that case, the prosecutor's instructions will be followed by the expiration of the 14-day period, and the prosecutor will submit the file with an examination prepared by the investigator. and will be submitted to the court, and notification of the results of the investigation or the minutes of examination (BAP) will be completed indefinitely. After the deadline or 14 days ends, the investigator's responsibility is transferred to the prosecutor's office, the investigator can apply for an extension of detention to the prosecutor, and the prosecutor applies to the prosecutor. You can extend the detention period of the suspect up to 40 days (Article 24(2), the prosecutor will be deducted from the delegation letter and prosecuted from the Sacred Attorney's Office (Article 143) Adult Guardianship Investigators Generally, you delegate the case file by confronting the suspect, witnesses and evidence in court (Article 207) (Yustisia, Sutinah, et al, 2015) Scope of duties and authorities of each law enforcement agency in the criminal justice system Functional coordination between the criminal justice system includes each of the above functions, including investigators and public prosecutors, court investigators, official investigators, legal advisor investigators, court 
prosecutors, and public prosecutors (Rianto, 2006. Yustisia, Pratiwi, et al, 2015).

Police Investigators and Prosecutors in Processing Criminal Cases in the Legal Territory of the Pontianak City Police

There are several cases P-19 and P-21 at the West Kalimantan High Prosecutor's Office and the Pontianak District Attorney's Office, which have increased every year. This certainly raises the question of the functional relationship and positive cooperation between the Police Investigator and the Public Prosecutor. The goals of the criminal justice system can be achieved effectively and efficiently. There is a need for coordination between law enforcement agencies (Khoidin, 2008).

Table 1. Perceptions Between Police and Prosecutors About Pre-Prosecution

\begin{tabular}{|l|l|l|}
\hline No & \multicolumn{1}{|c|}{ Police View } & $\begin{array}{l}\text { Public Prosecutor's } \\
\text { View }\end{array}$ \\
\hline $\begin{array}{l}\text { Sometimes the } \\
\text { unclear } \\
\text { instructions. The } \\
\text { Prosecutor gave } \\
\text { therapy to change } \\
\text { questions X, Y, Z, } \\
\text { but after that, they } \\
\text { were changed, } \\
\text { they even asked to } \\
\text { be corrected again } \\
\text { to become } \\
\text { questions A, B, C, } \\
\text { and so on. }\end{array}$ & $\begin{array}{l}\text { The police often do } \\
\text { not carry out the } \\
\text { instructions from the } \\
\text { prosecutor properly, } \\
\text { so they have to go } \\
\text { back and forth to kill } \\
\text { time. }\end{array}$ \\
\hline $\begin{array}{l}\text { Prosecutors often } \\
\text { do not understand } \\
\text { that general } \\
\text { criminal } \\
\text { investigators are } \\
\text { more complex than } \\
\text { special crimes. }\end{array}$ & $\begin{array}{l}\text { The police do not } \\
\text { understand that } \\
\text { special criminal } \\
\text { investigations are } \\
\text { more complex than } \\
\text { general crimes and } \\
\text { require extensive } \\
\text { knowledge. }\end{array}$ \\
\hline
\end{tabular}

\begin{tabular}{|c|c|c|}
\hline 3. & $\begin{array}{l}\text { The police should } \\
\text { be the main } \\
\text { investigator } \\
\text { because it is the } \\
\text { police responsible } \\
\text { for the } \\
\text { investigation } \\
\text { results. }\end{array}$ & $\begin{array}{l}\text { Prosecutors must } \\
\text { participate in } \\
\text { investigations } \\
\text { because they occupy } \\
\text { a central and most } \\
\text { responsible position } \\
\text { in court. }\end{array}$ \\
\hline 4. & $\begin{array}{l}\text { Prosecutors often } \\
\text { change the } \\
\text { contents of articles } \\
\text { of an indictment } \\
\text { from the police, } \\
\text { thereby weakening } \\
\text { the police } \\
\text { examinations in } \\
\text { court, even though } \\
\text { the police have } \\
\text { worked hard for } \\
\text { this. }\end{array}$ & $\begin{array}{l}\text { The police often } \\
\text { provide a weak legal } \\
\text { basis for an } \\
\text { examination to make } \\
\text { prosecutors weak in } \\
\text { court. The } \\
\text { prosecutor must } \\
\text { change again } \\
\text { because the } \\
\text { prosecutor is the } \\
\text { most responsible. }\end{array}$ \\
\hline 5. & $\begin{array}{l}\text { No-one supervises } \\
\text { criminal files that } \\
\text { the prosecutors do } \\
\text { not proceed to } \\
\text { court, while the } \\
\text { police can be } \\
\text { pretrial. }\end{array}$ & $\begin{array}{l}\text { No one can } \\
\text { supervise the police } \\
\text { if the file that the } \\
\text { prosecutor asked for } \\
\text { repair is not returned } \\
\text { to the prosecutor } \\
\text { again. There are } \\
\text { thousands of them. }\end{array}$ \\
\hline 6. & $\begin{array}{l}\text { If police } \\
\text { capabilities are } \\
\text { lacking, the police } \\
\text { personnel, not the } \\
\text { system, needs to } \\
\text { be improved. }\end{array}$ & $\begin{array}{l}\text { The incompetence of } \\
\text { the police must be } \\
\text { supported by a } \\
\text { system that provides } \\
\text { an accurate and fast } \\
\text { process of } \\
\text { proceedings. }\end{array}$ \\
\hline
\end{tabular}

Submission of notification of the commencement of the investigation.

Notification of the commencement of the investigation to the public prosecutor that the investigator has begun to investigate a certain crime. Article 109 paragraph 1 explains that an event that was initially suspected to be a criminal act turns out to be a criminal act (after going through the investigation process), notification is carried out after the investigation begins (Maukar, 2016). The investigator must carry out 
notification of the commencement of the investigation. Article 109 paragraph 1 of the Criminal Procedure Code is formulated explicitly and does not provide any alternative to investigators other than submitting the notification of the commencement of the investigation to the public prosecutor. In other words, the formulation of the article is imperative (Atmasasmita, 2010). Meanwhile, the public prosecutor must have followed the progress of investigating a case from an early age. Because the investigation results will be the basis for prosecution, from the beginning, the Public Prosecutor has coordinated with investigators and provided instructions that direct the conduct of the investigation to efforts to disclose data and facts needed for the prosecution of the case (Pratiwi, 2008).

In practice in the field, there are still many things that often happen that the public prosecutor receives the notification of the start of the investigation at the same time as the submission of the first stage case file. The act of submitting notification of the start of the investigation, simultaneously with the submission of the first stage of the file, violates the provisions of the Criminal Procedure Code. Because the Criminal Procedure Code determines the notification of the start of the investigation, it must be done when the investigator begins to conduct an investigation, not after the investigation has been completed by the investigator (Atmasasmita, 2010). Case files whose notification is submitted at the same time as the case files, generally, after being investigated, the investigation results are not complete. This causes the case file to be returned to the investigator with instructions for additional examination to be carried out to complete the investigation results (Adrianto, 2010). The two potentials, namely the technical capability of the investigator and the technical juridical ability, must be combined in such a way when investigating a case. Investigators and public prosecutors will automatically bring together the combination of these two abilities and skills in a consultation forum between investigators and public prosecutors. An analysis was carried out from the technical and juridical/legal aspects of evidence in the discussion. At that time, it was already known whether the results of the investigation of the case were complete or incomplete.

Suppose from the meeting between the investigator and the public prosecutor that the investigation results are complete. In that case, the investigator immediately submits the files he deems necessary and essential to the public prosecutor. The purpose of the meeting in the form of consultation/coordination will only be carried out if the investigator has previously been notified about the investigation that has begun. In general, case files where the notification of the start of the investigation is sent along with the submission of the first stage of the dossier turns out to be incomplete. 
This situation of repeated back and forth between investigators and public prosecutors needs to be prevented from happening. The KUHAP regulations it does not require that. The KUHAP requires a simple, fast and lowcost settlement of cases (Adrianto, 2010). Therefore, he said that based on the principle of functional differentiation between investigators and public prosecutors, it was also linked to the principle of mutual supervision and correlation between law enforcement ranks adopted by the Criminal Procedure Code. This is further strengthened by the aim of enforcing legal certainty that the Criminal Procedure Code wants to implement in strengthening our conclusion that coordination and communication and sling notifications are mandatory. Because if it is not mandatory in nature, the meaning of legal certainty contained in it will be lost. As a result, it will lead to all investigators' attitudes. In addition, as the Fatwa of the Supreme Court in the Working Meeting of the Supreme Court of the Republic of Indonesia Ministry of Justice and the Head of the High Court on February 15 to 19,1982 , which stated that the notification of investigators to the public prosecutor in the series of provisions of Article 109 paragraph 1 of the Criminal Procedure Code is a series based on the notification. It is a series of imperative judicial duties (Harahap, 2000).

In the Implementation of the Criminal Procedure Code (Attachment to the Decree of the Minister of Justice Number: M.01PW.07.03 of 1982 dated 4 February 1982) on page 24 point 1 , it is stated about the start of the investigation and the obligation to notify the public prosecutor article 109 paragraph 1 of the Criminal Procedure Code. Thus, it means that the Guidelines for the Implementation of the Criminal Procedure Code have determined that notification of the start of an investigation from the investigator to the public prosecutor is an obligation that the investigator must carry out. Meanwhile, investigators have an obligation to submit it to the public prosecutor, according to P.A.F. The Lamintang of an investigator must be seen as having started his investigation, that is, immediately after he has exercised his investigative authority as has been granted by law (Article 7 of the Criminal Procedure Code) (Lamintang, 1981).

Tolib Efendi said that if from the investigation results it was determined to proceed with investigative actions, at that time, the investigator's "obligation" was issued to notify the public prosecutor of the investigation. As for the implementation of the Criminal Procedure Code, it is stated that starting an investigation is if during the investigative activity there have been coercive measures taken by the investigator, such as summoning pro yustisia, arrest, detention, examination, confiscation, and so on (Tolib Effendi \& Yustisia, 2018). As a guideline for determining the meaning of the word 
"immediately" in relation to the notification, we hope that we can hold it as a legal basis for the Supreme Court which stated: "The word "immediately" in Article 34 of the Criminal Procedure Code must be interpreted within a reasonable time (within a reasonable time). How a good time depends on the situation and conditions in terms of complexity, the attitude of the investigator who immediately handles it without procrastinating (Without undue delay) (Lamintang, 1981).

\section{Coordination of notification of the} commencement of the investigation to the

\section{Public Prosecutor}

In the Criminal Procedure Code, which regulates the procedure for submitting notification of the commencement of an investigation to the Public Prosecutor. Article 109, paragraph 1 of the Criminal Procedure Code only explains that the investigator will notify the public prosecutor if the investigator has started an investigation. Thus, it means that the formation of the law leaves its implementation to law enforcement practice (Sugandha, 1988). While the method of notification of the commencement of the investigation by the investigator to the public prosecutor, it has been mutually agreed between the investigator and the public prosecutor that the notification of the commencement of the investigation shall be made in writing. For areas experiencing transportation difficulties, notifications can be made through electronic products (telephone, SSB, Telegram and so on) provided that written notifications still have to be adjusted later. The practise of notifying the start of the investigation will be carried out using the Serse A-3 form. The notification material for the commencement of the investigation, which is formulated in the form of Serse A-3 includes:

1. Notification at the start of the investigation of a criminal act that is equipped with the qualifications of a criminal act, the criminal articles suspected of being accompanied by the time and place of the crime being carried out with the basic conditions of the investigation consisting of, police reports, warrants for arrest and/or detention, documents other matters relating to actions that have been taken by investigators, for example, warrants and minutes of searches/confiscations.

2. The notification of the commencement of the investigation is signed by the investigator and confirmed with the position stamp.

3. In general, the notification of the start of the investigation is also attached with a report on the examination of the suspect and the witnesses carried out by the investigator (Ririsnawati, 2014).

Thus, the public prosecutor from an early age has obtained an overview of the case he will receive. Besides that, from an early age, the public prosecutor has directed the 
investigation to lay the foundations for the prosecution, which will be carried out later after the investigator receives the case file. Communication, consultation and coordination at this stage are still informal because education has not yet started, and the public prosecutor has not received notification of the investigation. So in a formal juridical manner, there has not been a cooperative relationship between investigators and public prosecutors. Such a relationship can also occur if the investigator faces doubts about starting the investigation of a criminal act. For example, the investigator has collected sufficient data and facts. Still, to decide whether the criminal event being investigated is a crime, an investigation can be carried out in the face of doubts (Rau, 2017).

In this connection, the Attorney General of the Republic of Indonesia in his Circular Letter Number: SE-013/JA/8/1982 dated August 20, 1982, concerning Factors that must be considered at the pro-prosecution stage, has reminded the public prosecutor that the perfection of the results of the investigation is a determining factor in the success of the prosecution. Public prosecutor, the relationship and cooperation between the investigator and the public prosecutor, either before or after notification to the public prosecutor regarding an investigation as stated in Article 109 paragraph 1 of the Criminal Procedure Code, must be continuously fostered to achieve perfection and completeness of the results of the investigation. according to the direction of the public prosecutor (Nugraha, 2020).

\section{CONCLUSION}

Based on the analysis of the problem, it can be concluded that the application of the principle of coordination between Polri investigators and public prosecutors in criminal cases in the jurisdiction of the Pontianak City Police during coordination between law enforcement officers, where the Police Investigators do not submit suspects and evidence to the Public Prosecutor. Arrears on cases P19 and P21 at the West Kalimantan High Prosecutor's Office and the Pontianak District Prosecutor's Office have increased every year. This shows that functional relationships and positive cooperation between the Police Investigators and Public Prosecutors are still hampered. In addition, there is a lack of coordination between the Police and the public prosecutor in resolving cases so that the investigation of criminal acts is related to the coordination and cooperation between the Police and the public prosecutor.

For the prosecution to be successful, a successful investigation is required. On the other hand, failure in the investigation will result in the failure of the public prosecutor in the prosecution process in court so that it affects the settlement of cases and hinders the implementation of the principle of coordination between Polri investigators and 
the Public Prosecutor. The lack of communication and coordination between the National Police and the public prosecutor is an important means so that there is no overlap in the implementation of authorities and obligations. Efforts that can be made in order to improve the relationship between the Police and the Public Prosecutor Good communication and coordination between the Police and the Public Prosecutor is needed. Public prosecutors can explain or instruct Polri investigators in examining criminal cases. Based on the Criminal Procedure Code, there is mutual supervision between Polri investigators and public prosecutors. Putting trust in the National Police in conducting investigations, thus facilitating the process for investigation productivity.

\section{REFERENCES}

[1] Adrianto, A. (2010). Penerapan Asas Praduga Tak Bersalah Dalam Penyidikan: Studi Kasus Pencurian Di Kepolisian Resort Bulukumba. [Diploma, universitas Islam Negeri Alauddin Makassar]. alauddin.ac.id/4871/

[2] Ali, Z. (2021). Metode Penelitian Hukum. Sinar Grafika.

[3] Atmasasmita, R. (2010). Sistem peradilan pidana kontemporer. Kencana.

[4] Djamin, A. (2007). Tantangan dan kendala menuju POLRI yang profesional dan mandiri. PTIK Press.

[5] Jonaedi Efendi\& Johnny Ibrahim, (2018). Metode Penelitian Hukum: Normatif dan Empiris. Prenada Media.

[6] Effendy, M. (2005). Kejaksaan RI: Posisi dan fungsinya dari perspektif hukum. Gramedia Pustaka Utama.
[7] Hantoro, N. M., Suhayati, M., Doly, D., Hairi, P. J., Sibuea, H. Y. P., \& Manao, D. F. (2018). Hakim: Antara Pengaturan dan Implementasinya. Yayasan Pustaka Obor Indonesia.

[8] Harahap, M. Y. (2000). Pembahasan permasalahan dan penerapan KUHAP. Jilid 1: Penyidikan dan penuntutan (Edisi kedua). Sinar Grafika.

[9] Justicia, T. V., Mahardika, A., \& Learning, G. (2016). KUHAP \& KUHP. Genesis Learning.

[10] Khoidin, M. (2008). Polri Dalam Perkembangan Hukum di Indonesia: Berbagai Pemikiran Tentang Paradigma Polri Menuju Polri Yang Bermoral, Profesional, Modern, dan Mandiri. Laks Bang.

[11] Kusumawinahayu, E. (t.t.). Efektifitas Peraturan Kapolri Nomor 14 Tahun 2012 Tentang Pengawasan Penyidikan Tindak Pidana di Polresta Pontianak Kota. Jurnal Hukum Prodi Ilmu Hukum Fakultas Hukum Untan (Jurnal mahasiswa S1 Fakultas Hukum) Universitas Tanjungpura, 2(3).

[12]Lamintang, P. A. F. (1981). Delik-Delik Khusus Kejahatan Yang Ditujukan Terhadap Hak Milik Dan Lain-Lain Hak Yang Timbul Dari Hak Milik. Tarsito.

[13] Limbong, D. (2017). Tinjauan Hukum Tentang Penerapan Asas Praduga Tak Bersalah Dalam Proses Penyidikkan Tindak Pidana Pembunuhan. 3, 8.

[14] Manik, J. D. N. (2018). Koordinasi Penyidik Polri Dengan Penyidik Pegawai Negeri Sipil Dalam Penyidikan Tindak Pidana di Bidang Pengelolaan Sumber Daya Alam. Jurnal Hukum PRIORIS, 6(3), 278-303.

[15] Maukar, F. R. (2016). Kewenangan Jaksa Selaku Penuntut Umum Menurut UndangUndang Nomor $30 \quad$ TAHUN 2002.LexAdministratum,4(4),Article 4. https://ejournal. unsrat.ac.id/index.php/administratum/article/v iew/11825

[16] Muladi. (1995). Kapita Selekta Sistem Peradilan Pidana. Badan Penerbit, Universitas Diponegoro. 
[17] Murtiono, D. B., \& Ik, S. (t.t.). Koordinasi Dan Pengawasan Penyidik Polri Terhadap Proses Penyidikan Tindak Pidana Oleh Penyidik Pegawai Negeri Sipil Di Polda Kalimantan Barat. 12.

[18] Mustofa, D. H. W. S. (2013). Kode Etik Hakim. Kencana.

[19] Napitu, A. P. (2016). Kajian Terhadap Hubungan Penyidik Polri Dan Kejaksaan Menurut Pasal 110 Dan 138 Kuhap. Lex Et Societatis, 4(9), Article 9. https://doi.org/10.35796/les.v4i9.14210

[20] Nugraha, Y. (2020). Optimalisasi Asas Oportunitas Pada Kewenangan Jaksa Guna Meminimalisir Dampak Primum Remedium Dalam Pemidanaan. Veritas et Justitia, 6(1), 213-236.

https://doi.org/10.25123/vej.v6i1.3882

[21]Pratiwi, A. D. (2008). Pelaksanaan Koordinasi Antara Penyidik Polri Dan Penuntut Umum Pada Tahap Pra penuntutan (studi kasus di kejaksaan negeri Surakarta dan poltabes Surakarta).

[22] I Made Pasek Diantha. (2016). Metodologi Penelitian Hukum Normatif dalam Justifikasi Teori Hukum. Prenada Media.

[23] Rau, B. (2017). Kajian Hukum Efektifitas Penerapan (Asas Contante Justitie) Asas Peradilan Cepat, Sederhana Dan Biaya Ringan. Lex Crimen, 6(6), Article 6. https://ejournal.unsrat.ac.id/index.php/lexcrim en/article/view/17028

[24] Rianto, B. S. (2006). Pemikiran Menuju Polri Yang Profesional, Mandiri, Berwibawa, Dan Dicintai Rakyat. PTIK Press.

[25] Ririsnawati, R. (2014). Koordinasi Penyerahan Dan Pengembalian Berkas Perkara Antara Penyidik Polri Dan Penuntut Umum (Studi Pada Kepolisian Resor Agam dan Kejaksaan Negeri Lubuk Basung). Universitas Andalas.

[26] Santoso, T. (2000). Polisi Dan Jaksa: Keterpaduan Atau Pergulatan? (Ed. 1., cet. 1). Pusat Studi Peradilan Pidana Indonesia.

[27] Saputra, A. (2019). Koordinasi Fungsional Antara Polri Dan Kejaksaan Pada Tahap Prapenuntutan Tindak Pidana Korupsi (Studi Pada Polres Pasaman Barat dan Kejaksaan
Negeri Pasaman Barat) | UNES Journal of Swara Justisia. http://swarajustisia.unespadang.ac.id/index.ph $\mathrm{p} / \mathrm{UJSJ} /$ article/view/76

[28] Sugandha, D. (1988). Koordinasi: Alat Pemersatu Gerak Administrasi. Penerbit Intermedia.

[29] Tolib Effendi, S. H. M. H., \& Yustisia, P. (2018). Sistem Peradilan Pidana: Perbandingan Komponen dan Proses Sistem Peradilan Pidana di Beberapa Negara. MediaPressindo.

[30] Undang-Undang Dan Peraturan Tentang Kepolisian Negara Republik Indonesia. (2008). VisiMedia.

[31] Watulingas, R. R., \& Kumampung, T. M. R. (t.t.). Proses Peradilan Pidana Terpadu Dalam Penyidikan Tindak Pidana Kekerasan Dalam Rumah Tangga Oleh Penyidik Polril Oleh: Jesika Nevita Tamuntuan2. 5, 11.

[32] Yustisia, T. V., Pratiwi, F., Sutinah, L., \& Pustaka, V. (2015). KUHP (Kitab UndangUndang Hukum Pidana) \& KUHAP (Kitab Undang-Undang Hukum Perdata). VisiMedia.

[33] Yustisia, T. V., Sutinah, L., \& Pustaka, V. (2015). 3 Kitab Utama Hukum Indonesia. VisiMedia. 